\title{
ESTUDIOS
}

\section{El agotamiento del modernismo en la poesía peruana}

os años iniciales de la primera guerra mundial encontraron a la poesía peruana plenamente modernista. * Si se acepta que el modernismo fué, en buena parte, una consecuencia literaria de la admiración americana por la cultura de las naciones líderes de la Europa de fines del siglo pasado y principios del actual, el desastre de la gran guerra, que hizo dudar a tantos europeos y no europeos de las bases de èse hasta entonces indiscutido liderato, había de hacer temblar también los cimientos del modernismo. De esa inquietud se halla una prueba evidente en la tesis doctoral presentada y pt1blicada en 1915 precisamente por el poeta peruano José Gálvez. En dicha tesis anotaba su autor los siguientes síntomas de la referida inquietud:

el hecho confusamente perceptible de reinar actualmente cierta anarquía literaria, la falta de una gran voz definidora y rotunda, la crisis que en este sentido parece advertirse en la literatura universal, pues no ocurre ahora lo que en otros tiempos de pontificados literarios de Hugo, Verlaine; la circunstancia de continuarse regando en los mismos campos ya fatigados de producción, y la quiebra de

* Ver mi anterior trabajo "La modalidad peruana del modernismo" en Revista Iberoamericana, xvii, 34, (enero, 1952), 225-242. Tanto dicha nota como las presentes páginas forman parte de un estudio general de la poesía peruana reciente. Agradezco a la John Simon Guggenheim Memorial Foundation y a Mills College la beca y la licencia sábática que respectivamente me concedieron para que pudiera llevarlo a cabo. 
algunas influencias magistrales... No puede negarse que ahora se siente alguna desorientación en cuanto a los modelos y cierto desencanto por los artificialismos que una persistente imitación ha producido... Yo creo percibir - y no tendría en verdad razones formales para comprobar lo que siento en este sentido-que ahora hay en América una especie de anarquía originalísima y típica que puede ser propicia al arte nacional... Ahora no podría señalarse una de aquellas tendencias deslumbradoras como la que anunciaron Gutiéterrez Nájera, Julián del Casal, Rubén Dario, Silva, Lugones, Herrera y Reissig y otros y se palpa más que se explica lo que digo aquí. 1

Testimonio de mayor excepción es éste por la doble calidad de poeta y de estudioso de su autor. Palpa Gálvez, cree percibir, siente, un hecho confusamente perceptible: desorientación, desencanto, repeticionismo, quiebra de influencias, de pontificados, cierta anarquía, cierta crisis literarias. Principio del fin de un pasado, crisis de un presente, posibilidad de un cambio. Una mirada al campo de la poesía peruana de los años bélicos confirma el testimonio de Gálvez. Los poetas que escriben por esos años escriben todavía en modernistas; en unos meses, en unos años no pueden deshacerse de las maneras, las actitudes y la retórica modernista, pero entre los más avizores o entre los mejores de ellos existió una actitud que buscaba salirse del modernismo.

Entre los poetas peruanos de esos años, modernistas todavía pero a la busca ya de una nueva tónica expresiva, puede escogerse a Abraham Valdelomar (1888-1919) como ejemplo típico. Valdelomar es, literariamente, un producto del modernismo pertiano, es un admirador confeso de los dos grandes peruanos modernistas: Chocano y Eguren, de los clásicos helénicos, de la latinidad, de Maeterlinck, pero también de los enérgicos Whitman y Kipling. ${ }^{2}$ Valdelomar seguía siendo modernista por la consciencia de su arte y de su voluntad literaria, por su actitud elitista, por su misma vida de literato que en el ambiente burgués de Lima hizo un culto de la pose, del snobismo, del escándalo; pero la inquietud que le hace ir sobre todo a la busca de nuevos temas literarios, le transforma ya en algo más que un simple corifeo del modernismo. Valdelomar fué, valga la expresión, un modernista terminal. En un movimiento que (a pesar de la admonición de Darío: "ser sincero es ser potente") ${ }^{3}$ había ido retorizándose en fórmulas de escuela, imitativas, Valde- 
lomar volvió en el Perú por los fueros de la sinceridad expresiva: "Yo digo lo que siento, amo lo que es bello, y realizo mi arte, lo mismo que canta el jilguero y florece el jacarandá y el sol alumbra. Hay dentro de mí una fuerza sobrenatural que me dice: Crea, piensa, canta." 4 Es decir, que aunque Valdelomar conservaba toda la consciencia artística del modernismo comenzaba también, con expresiones como la transcrita, a abrir en ella la brecha de un sobrenaturalismo, un nuevo intuicionismo, un neo-romanticismo que, cuando en etapas posteriores y en otros escritores llegue a su máximo impacto, aceptará lo onírico, to subconsciente y lo inconsciente como elementos de la poesía. Claro está que aquella sinceridad de Valdelomar se envuelve, pour épater les bourgeois, en garabatos snobistas: "En invierno leo a Maeterlinck, en otoño a Kempis, en primavera a Pitágoras, en verano a Kipling. Ahora me entretengo con Robert Browning." 5 Pero estos snobismos de Valdelomar reconocían una causa eficiente que él mismo expresó en estas palabras:

Yo comprendí a tiempo que un escritor necesitaba, ante todo, una gran popularidad, un público que se interesase por él, un mercado para sus obras... ¿ Pueden medir los majaderos que me condenan lo que significa ser trabajador en un país de ociosos? ¿Pueden medir el esfuerzo que significa mantener siempre latente la atención del público durante los cuatro o cinco años de mi labor de artista? 5

Dentro, pues, de esas limitaciones y de esa idiosincrasia ¿qué es lo que aportó de nuevo al modernismo peruano la obra literaria de Valdelomar? Lo que parece saltar a la vista es, ante todo. un cambio temático, el uso de temas que un modernista puro hubiera considerado poco poéticos, si no apoéticos y aun anti-poéticos: temas de infancia provinciana, de la vida familiar cotidiana, abandono de los paisajes versallescos, orientales o de cualquier otro exotismo por los paisajes y personajes peruanos, vistos cada día. Por ejemplo, un tema provinciano:

Mi infancia que fué dulce, serena, triste y sola se deslizó en la paz de una aldea lejana, entre el manso rumor con que muere una ola y el tañer doloroso de una vieja campana. 7 
O un tema de la vida familiar cotidiana:

La misma mesa antigua y holgada, de nogal, y sobre ella la misma blancura del mantel y los cuadros de caza de anónimo pincel y la oscura alacena, todo, todo está igual... Hay un sitio vacío en la mesa hacia el cual mi madre tiende a veces su mirada de miel y se musita el nombre del ausente; pero él hoy no vendrá a sentarse a la mesa pascual. La nisma criada pone, sin dejarse sentir, la suculenta vianda y el plácido manjar; pero no hay la alegria ni el afán de reír que animaran antaño la cena familiar; y mi madre que acaso algo quiere decir, ve el lugar del ausente y se pone a llorar...8

Y el abandono de lo exótico por lo local, lo común y ordinario pudiera ejemplificarse con el siguiente fragmento:

La luz de un arco parpadea, chocan sobre ella los insectos, cambia a mis pasos la quebrada rara silueta de los techos.

Duerme un cansado caminante en el dintel amplio del templo y allí en la esquina, junto a un poste, con gravedad se mea un perro. ${ }^{9}$

Al leer la poesía de Valdelomar no puede menos de impresionarnos la unanimidad con que los escritores, que nacidos a la literatura en el momento modernista tratan de escapar del modernismo, coinciden en la manera de buscar esta salida: Evaristo Carriegó (1883-1912), en la Argentina; Ramón López Velarde (1888-1921), en México; Luis Carlos López (1885-1950), en Colombia; Abraham Valdelomar (1888-1919), en el Perú. Tođos, por esos mismos años, van a lo cotidiano, lo corriente, lo poco "poético", lo nacional, lo provinciano, lo local, lo nimio, en busca de temas literarios que les alejen de lo exquisito, lo raro, lo cosmopolita, lo exótico del modernismo, lejos de las islas griegas y de los pabellones de Versalles, de las pagodas orientales, de marquesas y abates dieciochescos, de samurais y de musmés, de Mimi Pinsons más o menos montparnasia- 
nas. Naturalmente no siempre consiguen una ruptura completa con el modernismo - la tradición literaria es demasiado fuerte- pero la tendencia no deja de ser general, simultánea, impresionante.

Fué en los últimos ar̃os de su vida, accidentalmente cortada en 1919, cuando en jiras literarias que hizo por el Perú iba Valdelomar predicando el "sentido nacionalista o el criollismo en la literatura", e insistía en "el carácter intuitivo de los artistas contemporáneos que tienen que proceder por adivinación para crear un grande, bello y verdadero arte americano, definitivamente autónomo y libre de la presión europea." 10 Pruebas evidentes de la evolución de la teoría poética peruana, camino del alejamiento, del modernismo.

Sin embargo, no debe olvidarse que aunque Valdelomar represente esta dirección en la poesía peruana de los años de la primera guerra mundial no puede hablarse todavía de revolución poética sino, a mi modo de ver, apenas de una evolución poética, síntoma de la crisis de que Gálvez hablaba en su libro. A pesar de su nueva temática, Valdelomar no vivió el tiempo suficiente para llegar a romper completamente con el modernismo. Toda su obra muestra su admiración por los ídolos del modernismo y, fuertísima, la influencia directa de Gabrielle d'Annunzio. Hasta es posible que su d'annunzianismo de antes y de después de su estadía en Italia llegase a inclinarle a los caminos de la acción política en el Perú, forma atenuada de seguir las huellas condottierescas del d'Annunzio de la guerra y de la aventura de Fiume. Fué precisamente durante un jira política cuando le ocurrió a Valdelomar el desdichado accidente que le costó la vida.

Aunque poeta, y poeta importante en la evolución de la poesía del Perú, la obra mayor de Valdelomar fué, como él mismo đijo en una ocasión, más que sus "quince o veinte pequeños poemas":

treinta cuentos maravillosos, doscientas crónicas perfectas, ... cuatro o seis conferencias, un drama muy malo, un libro de historia, una tragedia estupenda (Verdolaga), ocho o diez artículos de crítica, fundar una revista de combate y revolucionar con sus tres únicos números; ... escribir dos, tres y cuatro artículos diarios en un periódico; colaborar en publicaciones extranjeras; ir una hora diaria, por lo menos, al Palais Concert; y dar, de tarde en tarde, un par de bofetadas; contestar el saludo; hacerse la barba...11 
La revista de combate a que Valdelomar alude es, naturalmente, Colónida, que publicó cuatro y no tres números, el 15 de enero, $1^{9}$ de febrero, $1^{\circ}$ de marzo y $1^{\circ}$ de mayo de 1916 , respectivamente. Conviene también no exagerar su importancia revolucionaria en la literatura peruana. Como Alberto Tauro lo ha visto muy bien, Colónida está inserta en el modernismo peruano, dentro del modernismo peruano, como también lo están lo que algunos críticos peruanos han llamado el "movimiento colónida", y hasta "la generación colónida." 12 Valdelomar admiraba al modernista Chocano y lo mismo hizo su revista: una fotografía de Chocano aparece en la carátula del primer número y poemas suyos en dos de los cuatro números publicados. Modernista, aunque de voz afinada y tono menor, es la poesía de Enrique Bustamante y Ballivián, de Alberto J. Ureta, de Adán Espinoza y Saldaña, que Colónida publicó. Modernista era la poesía de José María Eguren a quien Valdelomar dedicó el segundo número de Colónida, y poemas suyos, de Simbólicas, figuran en tres de los cuatro números. Tampoco de poesía extranjera nada heterodoxo, en relación con el modernsimo, figura en Colónida: Bandelaire, José María de Heredia. De los nuevos poetas peruanos, Percy Gibson (1885- ), mayor que Valdelomar, aparece en la revista con trozos de su "Evangelio democrático", es decir, de su época de modernista mundonovista. Y los poetas más jóvenes que Valdelomar que en Colónida figuran - Pablo Abril (1895- ), Alfredo González Prada (1891-1947), César A. Rodríguez (1891- ) José Carlos Mariátegui (1895-1930) — se muestran en esas poesias tanto o más inmersos en el modernismo que el propio Valdelomar. La "revolución" literaria de Colónida no pasó de ser una batalla modernista, dada principalmente en el número dos, en defensa y explicación de Eguren simbolista, todavía poco comprendido en aquellos años. Lo más estridente publicado por Valdelomar en esa revista fué un estudio de Federico More (1889- ), "La hora undécima del señor don Ventura García Calderón", en dos entregas (núms. 2 y 3), violento ataque a La literatura permana (1535-1914) ${ }^{13}$ de dicho autor, de la que Valdelomar había publicado en el nümero uno de Colónida unos trozos referentes a Palma, Prada y Chocano. More atacó a García Calderón por la atención que prestaba a la literatura de la época colonial y a la literatura peruana europeizante, extendiendo 
su ataque a casi todos los escritores peruanos, en contra de los cuales sienta la siguiente tesis:

Quien literatura peruana pretende hacer, obligado está a inquirir en el alma de nuestros más remotos ancestrales. $Y$ esos no son los marquesitos putrefactos y esmirriados y las tapadas niñacholescas del coloniaje. Debe subir el espíritu hasta los remotos milenios de los megalitos incaicos. Debe escudriñar en la tradición, oír de boca del pueblo la rapsodia que, desde la boca del lejanísimo ancestral, viene hoy al último retoño de una raza que entre frío y alcohol aún pimpollece. ${ }^{14}$

En resumen, salvo este manifiesto (uno de los iniciales del indigenismo pertuano reciente), Colónida no es muy distinta, por ejemplo, de Cullura (3 números: junio, julio, agosto, 1915), que Enrique Bustamante y Ballivián publicó como único director después que Valdelomar, ya en prensa el primer número, se hubo separado de la codirección de la misma. ${ }^{15}$ En efecto, Cultura también publicó poemas de Eguren, de Bustamante, de Percy Gibson, y, paralelo más moderado del artículo de Federico More, había incluído un buen trozo de la tesis de Gálvez sobre la Posibilidad de una genuina literatura nacional. ${ }^{16}$

Para mayor información sobre el carácter de la poesía de Valdelomar y sus amigos puede consultarse el volumen colectivo que con el título de Las voces muiltiples publicaron en 1916. ${ }^{17}$ Los poemas de Valdelomar en ese libro muestran la tendencia temática evolutiva, transicional, de los ejemplos antes citados; pero los poemas de los siete amigos que con él colaboraron en el volumen están todavía dentro de la retórica modernista, aunque por lo general en la retórica del modernismo de tono menor, con algún ligero toque de mundonovismo en un par de casos. Pablo Abril (1895- ), el más joven de los poetas del libro, decía, por ejemplo:

Amarte así, de nuevo; sollozar en la sombra mientras mi labio trémulo te bendice y te nombra; sentir que eres como una divina transparencia; hallar en cada fuente la euritmia de tu risa, y dejar en el alma voluble de la brisa la ternura inefable de alguna confidencia. ${ }^{18}$ 
Los sentimientos no pueden ser menos sorprendentes, ni el vocabulario más esperado, ni la adjetivación más completamente estereotipada dentro del modernismo. $Y$ pasando del poeta más joven al de más edad (después de Valdelomar) que figura en Las voces múltiples, el Federico More (1889- ) iconoclasta del ensayo antigarcíacalderoniano, lo más audaz que se encuentra en su aportación poética a ese volumen es:

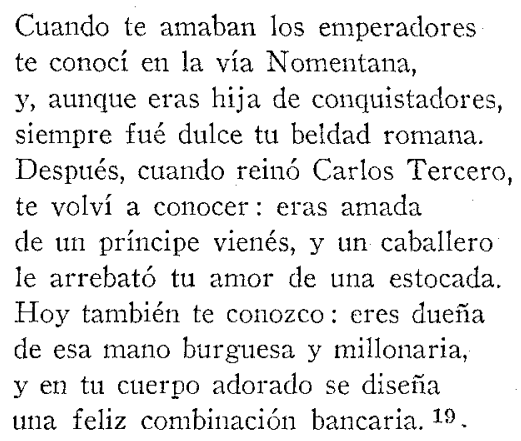

En este poema realmente no parece Federico More haber inquirido en el alma de los remotos ancestrales de los megalitos incaicos. $O$, si se quiere algo intermedio entre el trémulo sollozar de Pablo Abril y la incipiente ironía social de Federico More, Antonio Garland ofrece: "Zíngaros, luces, champaña ... El Rag-time va a terminar /. la música está en la noche, y el leit-motiv es amar..." ${ }^{20}$ del más barato parisianismo.

No se exagere pues la importancia de los "colónidas", pero apréciese la personal y simbólica de Abraham Valdelomar en la evolución de la poesía pertrana hacia una salida del modernismo así como su paralelismo con las notas análogas en la poesía de escritores contemporáneos suyos que en otros países hispanoamericanos evolucionaban en la misma dirección por parecidos motivos.

Otro poeta peruano, más joven que Valdelomar, inquieto por los años de la guerra europea con la misma inquietud literaria que él, y típico también de un esfuerzo de paso hacia afuera del modernismo, es Juan Parra del Riego (1894-1925). Sus primeros poemas, publicados en Lima por el año de 1912 le muestran muy claramente bajo la influencia del Darío parnasiano y del Chocano objetivista: 
Los viejos marineros en el recogimiento silencioso del muelle, con las pipas al viento y las gorras azules puestas a medio lado, conversan de naufragios en su jerga grotesca y hacen recordaciones del buen tiempo pasado contemplando los barcos que tornan de la pesca. 21

Al año siguiente, cuando tenía apenas diecinueve, ganó Parra la Flor Natural en los Juegos Florales del Barranco con un "Canto a Barranco" en doce sonetos: "E1 mar", "El parque", "La pila y los jardines", "Los álamos", "Los jacarandás", "Los molinos", "E1 puente de los suspiros", "El viejo párroco", "La Virgencita de la gruta", "Chorrillos visto desde Barranco", "Miraflores visto desde Barranco", y "Surco." 22 Sus mismos títulos indican el esfuerzo descriptivo y también la temática anclada en lo familiar; con todo, la producción de Parra desde 1913 hasta su partida del Perú, por 1917, dispersa en periódicos y revistas, presentaba los inevitables "Cisnes negros", las sabidas melancolías "De un amor que se fué soy la sombra doliente", y el simbolismo de "La tarde es una ojera de infinita tristeza", todo ello del más pervasivo modernismo. ${ }^{23}$ Pero también desde muy pronto se nota en Parra del Riego una tendencia al humor en la poesía:

Al compás de las violas
del aire ensoñador de la mañana
bailan, bailan las olas.
Y alrededor del circo marino hay infantiles
risas, gritos, aplausos y un ibravo! colosal. 24

Humor que desarrolla luego más certeramente, por ejemplo, en la famosa "Mattinata": "Buenos días, Pierrot, / le dije al blanco sol de esta mañana..." 25 También aparece en Parra un sentido de lo vernáculo, lo local, lo diario, lo íntimo, que le enlaza con la actitud poética de Valdelomar y de sus coetáneos antes mencionados; cosas como "Tierra de Chiclayo que a cantar me animas"; Lambayeque "igual desde los tiempos de lanza que festejas"; "El poeta canta el mar de Salaverry"; etc. ${ }^{26}$ En tales poemas abandona lo cosmopolita, lo lejano, lo exótico y lo vago del modernismo. Vale decir que en los años de la guerra y en el Perú, Parra, como Valdelomar, osci- 
la entre el modernismo y su salida; mas Parra, aunque murió a la misma edad que Valdelomar, pero seis años más tarde que éste, pudo completar la evolución hacia formas ajenas ya a la retórica modernista que el iniciador no alcanzó. Entre el año 1919 en que murió Valdelomar y el 1925 en que murió Parra del Riego, las inquietudes nuevas de la post-guerra, el tipo de vida que en ella se generalizó, le aytudaron a completar la iniciada evolución literaria. La democratización de la máquina: motocicleta, automóvil, avión; el triunfo del gusto por lo dinámico y lo deportivo entre el gran público: football, tennis, natación, carreras, olimpiadas; el ritmo más staccato de la existencia, los pudo llegar a reflejar Parra en una poesía de imágenes nuevas, maquinísticas, deportivas (hasta en la expresión del amor), de ritmo más ligero, y de tono más de estadio que de café literario del que jamás pudo apercibir Valdelomar. En la manera de Juan Parra del Riego de los años de la post-guerra ve Estuardo Núñez la herencia de la sonoridad de Chocano, de la sinceridad de Valdelomar, del maquinismo de Marinetti, del deportismo de Montherlant, y del vitalismo de Whitman y Unamuno. ${ }^{27} \mathrm{Y}$, en efecto, Parra me parece poseer la facilidad imagística y sonora de un Chocano, pero con imágenes obtenidas de un mundo de atletismo, de fisiología deportiva, de vida de equipo, que Chocano no practicó. Tiene Parra la sinceridad y el amor por la belleza de un Valdelomar, pero sinceridad expresada y belleza encontrada en objetos y objetivos que Valdelomar no alcanzó a disfrutar (o que quizás con su monóculo y stu dandysmo, sus tertulias del Palais Concert y sus redacciones de periódico, no hubiera sabido disfrutar). Es posible que Parra fuera influido por las imágenes maquinísticas del futurismo de Marinetti, ya bien establecido en Europa desde antes de la guerra, pero en cuanto a la influencia del deportismo de Montherlant (1893- ) sobre el de Parra del Riego no debe olvidarse que un poema como, por ejemplo, el "Polirritmo dinámico de la motocicleta", de Parra, 1leva fecha de $19222^{28}$ mientras que Le Paradis à l'ombre des epées y Les onze devant la porte dorée, de Montherlant, son de 1924, y Les bestiaires de $1926 .{ }^{29} \mathrm{E} 1$ energismo y el vitalismo de la poesía de Parra sí me parecen estar en paralelo a los de la poesía de Whitman y de Unamuno. Como en la de éstos el poder intelectivo es superior en la poesía de Parra incluso al poder de creación de imágenes, con ser éste muy grande. Lo contrario sería lo que 
hubièra ocurrido si Parra hubiese sido un adepto a los primeros -ismos de la post-guerra, que combatían el pensamiento y la ideación en la poesía. En efecto, nada menos futurista, cubista, dadaísta, que una estrofa de "Al motor maravilloso", por ejemplo, de Parra:

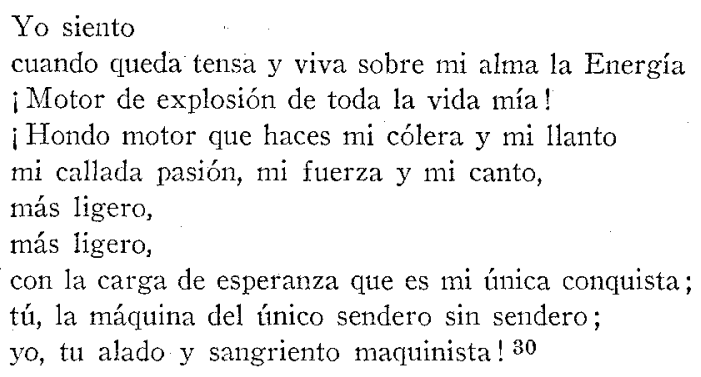

Aquí el maquinismo es ocasión de imagen y metáfora; pero lo hondamente sentido es el pensamiento expresado, mucho más que la fórmula que lo reviste. Igualmente en el "Polirritmo dinámico de la motocicleta", el maquinismo y el deportismo son también imagísticos, trampolines para lanzar la emoción, el sentimiento del autor:

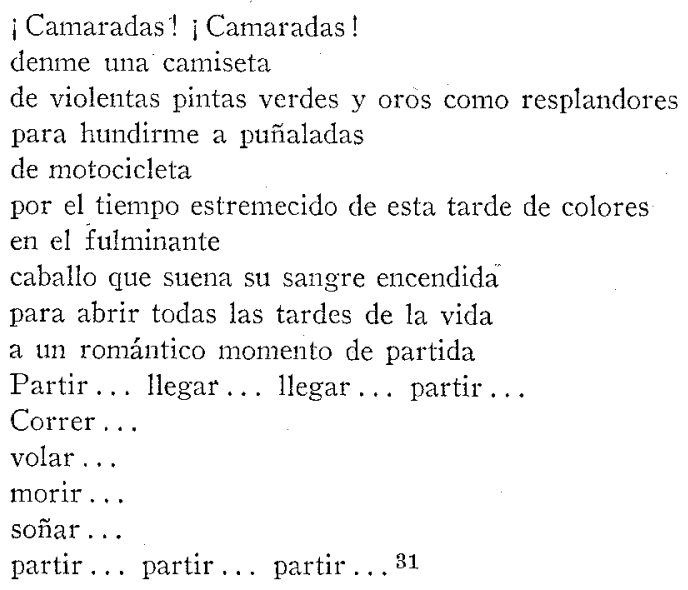

Es decir que Parra comenzó su vida de poeta, modernista aún; pronto buscó en la temática del humor, de lo cotidiano, del mundo a su alrededor, un comienzo de salida del modernismo; y, por fin, acabó su vida poética en una situación en que utilizaba los objetos 
de una nueva época social - la máquina, el deporte, la vida activapero no como valores per se sino como atuendo de un pensamiento que vacilaba todavía entre los dos mundos, aquél en que nació y aquél en que estaba muriéndose:

Es el momento universal, que se diría que hace flotar a la personalidad humana sobre un mar oscuro en el que ya nos parece divisar costa salvadora y... nada; y en el que nos volvemos a caer indecisos, amorfos, llevados por cien corrientes opuestas; pero en el que sentimos la palpitación tumultuosa de algo que se aproxima, grande, colosal, fraterno... Yo quiero ir por los caminos claros y viriles del mundo: la fe y el esfuerzo. Quiero pertenecer a esos nuevos organismos sociológicos triunfantes... ${ }^{32}$

Es en ese esfuerzo de voluntad de lo nuevo donde se inserta la poesía última de Juan Parra del Riego. Hacia ella había ido marchando desde su iniciación modernista y peruana de 1912.

Un numeroso grupo de poetas podría seguir ejemplificando la poesía peruana de los años de la primera guerra mundial, tendiente hacia algo nuevo, que venía, todavía incipiente, todavía en tanteo. Voy a limitarme a mencionar unos pocos ejemplos más, deteniéndome un momento en cuatro poetas algo más jóvenes, con una excepción, que Parra del Riego, originarios de los dos centros literarios por entonces más activos fuera de la capital peruana, aunque a Lima, y a otras capitales americanas y europeas, fueron pronto a dar.

En Arequipa, como en el resto del Perú, había sentado sus reales el modernismo desde fines del pasado siglo cuando, según Mostajo, Jorge Polar "fué el primero que, en el Perú, dió a su cláusula galana el corte parisiense del modernismo." 33 Por los primeros años del novecientos, uno de los más notables modernistas arequipeños fué Augusto Renato Morales de Rivera, poeta al que destrozó físicamente la bohemia alcohólica y que, en vida, aparte de innumerables poemas en periódicos, revistas y álbumes, publicó un solo libro, $C i$ rrus (1909). ${ }^{34}$ Por los años de la guerra, Percy Gibson Moller (1885- ) alternaba el mundonovismo de poemas como su "Evangelio democrático" y su Jornada heroica (1916), ${ }^{35}$ con una serie de poemas paisajistas, de visión de la vida diaria, local, provinciana, a 1o Valdelomar, lo Luis Carlos López, lo López Velarde, etc., posible destilación del tono de las "eglogánimas" de Julio Herrera y 
Reissig. Poemas como "Oh, dulce amanecer", "Tingo", "El gallo", etc., que vienen siendo piezas de antología, fueron publicados entonces en revistas y periódicos por este poeta reacio al libro. ${ }^{36}$ También por los mismos años publicaba poesías, prolíficamente, César A. Rodríguez (1891- ), autodidacta, voraz lector, hombre reflexivo y de espíritu filosófico. Su obra hay que ir descubriéndola en las publicaciones periódicas; su único libro, La torre de las paradojas (1926), ${ }^{37}$ es hoy inhallable, y no he logrado verlo ni en el Perú donde no existe en la Biblioteca Nacional, de Lima, ni en la de la Universidad Nacional de San Agustín, en la misma Arequipa. Por los años de la guerra, que en este momento nos ocupan, Rodríguez escribía poemas como "Saltimbanqui", "Bizantina", "Arequipa" y "Blasón", 38 o "Psicología felina", "Tarde antigua", "A toda velocidad", y "Miserere", ${ }^{39}$ muy modernistas.

Estos poetas y otros escritores y artistas se agrupaban en Arequipa en tres reuniones. Una, que tomó el nombre de "El Aquelarre", centrada en Percy Gibson, César A. Rodríguez y Augusto Renato Morales de Rivera, reunía también al músico Dunquer Lavalle, Federico Segundo Agüero Bueno, Belisario Calle (1894- ) y Natal Llerena. Parece ser que este grupo publicó una revista titulada $E l$ Aquelarre (Arequipa: Imprenta Ibáñez), que no he hallado, y de la que salieron cuatro números en 1916 ó 1917. Otro grupo arequipeño lo constituían Miguel Angel Urquieta, Alberto Hidalgo (1897-

), Luis de la Jara y Alberto Guillén (1897-1935). Urquieta e Hidalgo discrepaban literariamente de Gibson y Rodríguez, e Hidalgo publicó una revista literaria titulada Anunciación (que tampoco he encontrado), que inclúa una sección polémica titulada "Bombos y palos." Un tercer grupo, surgido por 1917, "La Bohemia Andina", reunía a Alejandro Peralta (d 1899?- ) Arturo Peralta, Emilio Armaza (1902- ) y a otros jóvenes escritores (que más tarde constituyeron uno de los núcleos del indigenismo) con obreros y artesanos. ${ }^{40} \mathrm{La}$ impresión que estos datos dejan es la de cierta actividad y discusiones literarias en la segunda ciudad del Perú.

En este ambiente comenzó a actuar en la literatura Alberto Hidalgo Lobato (1897- ), que por esos sus juveniles años, coincidentes con los de la primera guerra mundial, andaba ya haciendo ruido por los círculos intelectuales de Arequipa. A su primer libro de versos, Arenga lírica al Emperador de Alemania y otros poemas (1916), 
le puso un prólogo su amigo Miguel Angel Urquieta, en el que señalaba que Hidalgo, librándose de las influencias de Hugo, Verlaine, Baudelaire, Darío y Herrera y Reissig, sentía fuertemente la de Walt Whitman, al mismo tiempo que era un "Enamorado sin examen de la arenga futurista y relampagueante de Marinetti que proclama a toda voz estentórea la guerra como única higiene del mundo." ${ }^{41}$ Debe señalarse, sin embargo, que del modernismo descienden directamente poemas de ese libro tales como "Reino interior", por ejemplo: "Soi un fuerte labriego i más fuerte poeta; / Mi alma es ática, pura, buena, sentimental. / A veces soi alegre como una pandereta / $\mathrm{i}$ soi a veces triste como un canto rural." ${ }^{42} \mathrm{La}$ influencia de Whitman aparecerá quizás en el energismo formal de otros poemas de ese libro que no ciertamente en su contenido, que a menudo hubiera horrorizado al poeta de Camden:

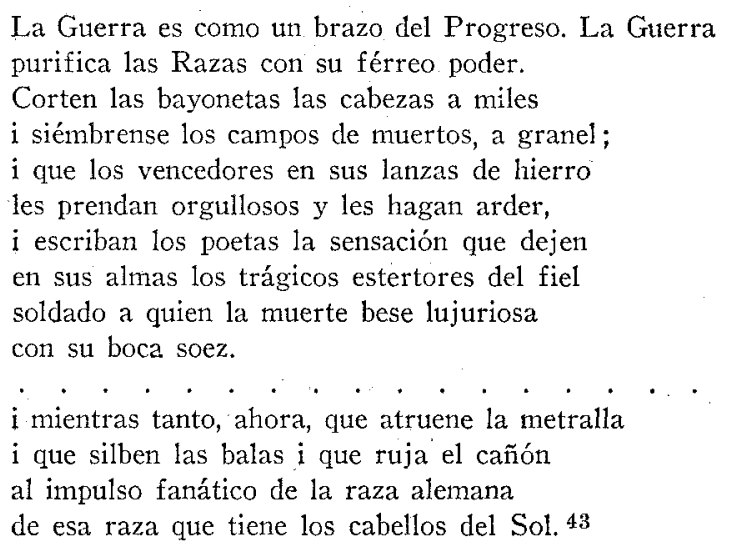

Este poema presenta indudablemente en su contenido mucho más la influencia de los manifiestos futuristas de Marinetti que la de la poesía de vida, y no de muerte, de Whitman; pero sobre todo parece más que nada resultado del afán inmoderado de un muchacho de llamar la atención, especialmente cuando tal elogio de la guerra y de la Alemania de Guillermo II se hacía en un país cuyo mundo literario era tan francófilo como el del Perú de aquellos días. Este deseo de llamar la atención es obvio y fuertísimo en ese escritor que desde entonces mismo se sentía gran poeta, genio: "Me siento inmensamente superior a los hombres / i pongo de los genios junto a sus gran- 
des nombres / mi nombre que resuena como un noble tambor." ${ }^{44}$ No en vano había indicado Urquieta que Hidalgo era "un Narciso de su valer intelectual." 45

Este joven, que había insertado en su inicial revista una sección de "Bombos y palos", debió saber organizar su propio bombo, porque en su segundo libro de versos, que publicó el año siguiente, Panoplia lírica (1917), ${ }^{46}$ pudo incluir un pórtico de Luis Fernán Cisneros, un estudio de Abraham Valdelomar y unas notas (todas elogiosas, naturalmente) de don Manuel González Prada, de don Manuel Ugarte y de una serie de escritores peruanos y extranjeros a los que debió remitir su primer libro, como lo había remitido a Clemente Palma. Este publicó en la revista Variedades un interesante juicio sobre Arenga lírica, involucrando un juicio sobre las nuevas tendencias literarias en general:

nos hemos convencido de que todos estos visajes y aspavientos líricos de los modernistas de hoy, que ya no se llaman modernistas, como decíamos nosotros, sino futuristas, son mentirijillas sinceras... búsquedas afanosas de la senda en la natural desorientación de los pocos años. Es, se puede decir, el ritual obligado de la sangre joven... un jovent de Arequipa de bastante talento y positiva madera de poeta que me ha remitido [Arenga lírica con] un "Canto

- a la guerra" pirotécnico, escandaloso y escrito más que en loor de la fuerza bajo la influencia de las mentecatadas de Marinetti... es un mozalbete de positivo talento. Hoy no es prudente darle consejos: hoy se cree el centro del mundo y. no hay más remedio que sonreírse con benevolencia. No hay que contrariar a este niño, que está en pleno acceso de tos convulsiva. Dejadle patalear, ponerse rojo e hipar todas las cosas líricas que se le atragantan y pugnan por salir. Puede que cuando se tranquilice, encuentre realmente la forma y la idea original que hoy quiere arrancar con manotones alocados en los campos de la epatante exageración y de la pose...47

Exhibe Palma en esta apreciación su habitual dogmatismo crítico y muestra paralelamente la dificultad de comprensión que parece inevitable en los momentos de cambio de gusto literario entre los hombres de la generación formada en uno y los jóvenes que comienzan a formar el nuevo gusto al influjo de la mayor receptividad de 1a juventud hacia cambios a los que aquéllos se resisten; pero Palma no deja de acertar, en el caso de Hidalgo, con ese acerado "mentiriji- 
Ilas sinceras". A mentirijillas suenan, en efecto, los conceptos belicistas de la "Arenga lírica al Emperador de Alemania" y del "Canto a la guerra" en la pluma de un joven sentado a un pupitre de escritor en Arequipa, a varios miles de kilómetros de los frentes de batalla. $\mathrm{Y}$ más de mentirijillas parecen todavía cuando en las colecciones de la prensa peruana de aquellos años se leen frecuentes noticias acerca de residentes del Perú, franceses, alemanes, inglèses, italianos, que partían para Europa y que allí se batían y, en buen número, resultaban heridos o muertos, y hasta no infrecuentes noticias de ciudadanos peruanos que se alistaron en los ejércitos combatientes y lucharon y murieron en la guerra, como José García Calderón, por citar un solo ejemplo. Pero esas mentirijillas de contenido y de realidad son "sinceras" en el sentido que les da Clemente Palma de búsqueda de algo nuevo, original, distinto a lo anterior, con que la gente joven literaria del Perú -en este caso, un joven, Alberto Hidalgo - trataba de expresar novedosamente el nuevo mundo que confusamente sentía estarse fraguando con la guerra.

Por esto en el citado segundo libro de versos, Panoplia lírica, en el que Hidalgo recoge parte de su poesía anterior influída por el modernismo en general ("Reino interior"), o por el de Herrera y Reissig en particular ("La yanta", "En la chichería"), y varios de sus poemas belicistas ("Arenga lírica al Emperador de Alemania", "Canto a la guerra"), insiste, con su afán de ver y expresar un mundo distinto al de sus antecesores, en las "mentecatadas de Marinetti", que dijo Palma, con poemas como "La nueva poesía (Manifiesto)":

\footnotetext{
Dejemos ya los viejos motivos trasnochados i cantemos al Músculo, a la Fuerza, al Vigor ;

Poesía es la roja sontisa del cañón;

Poesía es el brazo musculoso del Hombre;

Poesía es la fuerza que produce el Motor; el acero brillante de la Locomotora que al correr hace versos a la Velocidad; el empeño titánico del robusto minero que escarba las entrañas del hondo mineral; el veloz aeroplano, magnífico $y^{\prime}$ potente, sobre cuyas dos alas silba el viento procaz .. ${ }^{48}$
} 
Manifiesto en que igualmente repite los demás motivos de "los tranvías eléctricos", "las casas de cien pisos", "los barcos trasatlánticos" y la inevitable "Motocicleta." Como Parra del Riego, Hidalgo busca en los objetos materiales de la nueva civilización $\mathrm{y}$ en un culto de la dinámica y el vigor físico, las bases que sustenten una nueva visión de la belleza, distinta de la que habían percibido sus antecesores inmediatos. Que muchas veces esta nueva visión sea tan poco personal en Hidalgo, tan imitativa, como en su "Oda al automóvil": "El Auto es una clara fuente de poesía / el Auto es más hermoso i artístico que el Día, / más sereno que la Noche / i más bello que la Mujer...", ${ }^{49}$ obvio rifacimento de la frase de Marinetti que afirmaba que un automóvil de carreras es más hermoso que la Victoria de Samotracia, ${ }^{50}$ podrá reflejar pobreza poética en el Hidalgo de esos versos, pero no le hace perder valor como documento de época, como ejemplo de una tendencia, que es lo que aquí históricamente interesa. $\mathrm{E}$ interesa también para la historia de ese momento literario darse cuenta de que esta tentativa de cambio de expresión en la poesía fué algo voluntario, consciente, por parte de este escritor que, en efecto, dice en el prólogo de su siguiente y tercer libro de versos, Las voces de colores (1918):

Nos ha cabido en suerte ser los iniciadores en nuestro país de un movimiento de renovación literaria... Este movimiento renovador consiste en haber infiltrado en la poesía castellana la enjundia filosófica del Futurismo, sin hacer uso de la forma en que sus iniciadores lo envolvieron...51

La enjundia filosófica del futurismo, tal como aparece en los versos de Hidalgo en sus tres primeros libros - y en el cuarto, Joyería (1919) - ${ }^{52}$ parece ser el elogio de la fuerza guerrera, la violencia, la antidemocracia, ${ }^{53}$ el músculo, el deportismo, el maquinismo y, más que nada, la repudiación de los valores del pasado inmediato. Es este último punto el que conviene recalcar porque -fracasase o no Hidalgo en la expresión literaria de su propósito- éste es el aspecto tendencial que lo apareja a los demás escritores jóvenes de su día, aunque en los demás escritores la tendencia o tendencias filosóficas que sustenten su deseo de cambio sean distintas, y aún antagónicas, a las de Hidalgo. En Hidalgo, a la repudiación de los valores del pasado inmediato se une el desprecio por ello que se expresa 
en las formas escandalosas, en el propósito de endiosamiento del poeta, ${ }^{54}$ y en los sarcasmos y en los insultos que dirige (a veces muy groseramente, sobre todo en sus obras en prosa) a todas las autoridades constituidas, políticas, sociales o culturales. ${ }^{55}$

Ante la programática de rebeldía literaria de Hidalgo llama, sin embargo, la atención la relativa timidez de su preceptiva de esos años: "El verso castellano, en nuestro concepto, para ser tal deberá tenetr rima ... usamos a veces el verso libre, libre tal como nosotros lo entendemos... en verso arrítmico, pero ninguna vez desprovisto de rima." 56

Por otra parte las obras poéticas de Hidalgo en los últimos años de la gran guerra europea son menos estridentes que las de los primeros años de la misma guerra y mucho menos violentas que lo que su teoría y su programa y sus libros en prosa coetáneos permitirían suponer. Léase un poema como "Zenit", por ejemplo, de 1918, vagamente creacionista. ${ }^{57}$ Acaso la labor poética de Hidalgo en esos años del 1916 al 1920 pudiera resumirse con las palabras de dos versos suyos de la época: el poeta "satisfecha su hambre, su sed, su rebeldía, / se contempló los biceps, alegre. Amanecía." 58 Toda el hambre y la sed de novedades, toda la rebeldía poética, gritada más que realizada en esos años por Hidalgo, pudiera ser vista como un flexamiento de biceps para futuras labores, como una simple manifestación del Zeitgeist de los años bélicos, de su confusionismo, de su desorientación, de la consciencia de querer ser distinto, del deseo de ruptura con el pasado inmediato, del querer estar listo para el momento en que amaneciera, con una nueva vida, una nueva poesía.

Conterráneo y contemporáneo de Alberto Hidalgo (1897- ) fué Alberto Guillén (1897-1935), aunque ligeramente más tardío que aquél en iniciarse públicamente en la literatura. Su "revelación" parece ser que se efectuó con motivo de un concurso organizado (en 1917) por el periódico arequipeño El Heraldo. ${ }^{59} \mathrm{Su}$ primer libro, Prometeo, apareció en 1918, año para el cual ya llevaba Hidalgo publicados cinco volúmenes de prosa y verso. La aparición de Guillén en las revistas limeñas es de 1918, tres años más tarde que la de Hidalgo. ${ }^{60}$. Y fué el propio Hidalgo quien en un "Pórtico" a Prometeo, dice: "Te entregaste a la Poesía bajo mi noble auspicio / de Poeta anunciador, / i al hacerlo me diste el terrible suplicio / de ser maestro a los veintitantos años." "61 En efecto, comienza Guillén 
a literatizar en el tono egocéntrico y con el mismo alto concepto de sí mismo que había mostrado Hidalgo desde sus comienzos:

Soi de los Puros. Mi sangre es jugo de viñas nuevas. Soi de los jóvenes bárbaros, de los bellos salvajes americanos, que principiamos a vivir. I balbuceo Cantos como los Bardos primitivos. / Soi una flor de Razas. Soi un Vértice. Sobre mis veinte años pesan veinte siglos. Antes de mí Dionisios. Por encima de mí, el Poeta Sumo: Jesús el Nazareno. Todos colaboramos en la obra eterna. I a través de los Siglos, los Grandes nos damos la mano. ${ }^{62}$

Dos poetas jóvenes que se consideraban grandes genios, no era probable que siguiesen siendo afectos por mucho tiempo. He visto que Hidalgo acusa a Guillén de plagiario y que Guillén olvida a Hidalgo en ocasión de que, en una interview en el extranjero, se le ofrece hacer una lista jerárquica de poetas peruanos. ${ }^{63}$

La poesía de Prometeo muestra ante todo el pensamiento egocentrista del poeta, el alto concepto que tenía de sí mismo. En una "Epístola al Señor San Pablo", le dice, por ejemplo: "Tuyo es el Verbo que abre llagas en los corazones / de fe viva, i la lira que amansa los leones / es mía. Soy tu hermano. Somos iguales, Pablo." 64 Con el testimonio de este libro, más cierta que en Hidalgo me parece en Guillén la lectura y la lección de Whitman: "Mi canto es un comento / divino de mí mismo." "65 Su filosofía de la vida, oposición a la melancólica tristeza de la generalidad de los modernistas peruanos, es toda optimismo, de confianza en sí mismo, de victoria del hombre sobre los homúnculos, sobre el mundo a su alrededor, y sobre el destino, y resulta quizás la aportación más enfática de Guillén a la poesía peruana de ese tiempo. Porque por los mismos años la filosofía futurista de Hidalgo, de admiración por la fuerza y la energía per se, ponía más que nada su énfasis en la negación destructora del pasado y de lo contemporáneo que no coincidiese con su humor y su gusto; mientras que Guillén en Prometeo, presentando menos futurismo aparencial que Hidalgo, pone más énfasis en la afirmación que en la negación, y es más positivo, menos preocupado de volver la espalda al pasado que la cara a lo nuevo: "Soi ... Mi sangre es... Soi ... Soi ... Soi ... colaboramos ... nos damos la mano", son los verbos esenciales, positivos, de una de las citas anteriores. Hay en Prometeo un goce de afirmar el ser hombre en sí mismo y por sí mismo (grande hombre, semi-dios, si se quiere, pero 
con raíces humanas): "Me siento contento de mí mismo: / Hombre soi ; como tú, como todos, / pero mi alma es grande; / siento latir en mis arterias la sangre de los mundos." 66 No es en la forma, sino en el contenido, donde el primer libro de Guillén representa cambio respecto al modernismo; es en ese sentido de que Guillén quiere decir algo, expresar una distinta filosofía (discutible en el campo de los valores filosóficos, pero importante para él), en donde suena un tono diverso al de la poesía de pre-guerra. Ese querer ser joven bárbaro, bello salvaje americano, que principia a vivir, suena a algo diferente del "iOh, qué anciano soy, Dios santo; / oh, qué anciano soy!" y del "mi querida es de París", de Rubén. ${ }^{67}$

En la poesía del segundo libro de Guillén, Deucalión (1920), el egocentrismo del autor continúa, casi obsesivamente. Posible es que sea parte de un mecanismo de compensación psicológica: "Un metro sesenta / i tantos centímetros de estatura: / su osamenta / es una vertical hacia la altura. / ... Cuando le ve la gente / pasar, todos le miran / la talla i no la frente." 68 Pero la reiterada aserción del valor de la voluntad y la energía individuales continúa igualmente siendo el básico mensaje filosófico y poético de Guillén: "¿Quién te dará todo eso?, dijo el / Temor - Yo a mí, le respondí." ${ }^{69}$ Es en la expresión de esta filosofía donde me parece residir la importancia tendencial que Guillén representa, con Hidalgo, en la literatura peruana de esos años, tendencia que aunque indudablemente inspirada en el egocentrismo y el caudillismo literarios y vitales de Chocano, llevan estos jóvenes a sus últimos extremos.

Frecuentemente la consideración de las consecuencias de esa filosofía en la personalidad y en la actuación civil de Guillén se interfiere en el examen de su poesía. Porque Guillén al querer, como Hidalgo, abrirse paso, to hace, de libro en libro, en verso y en prosa, y en su actitud y su actuación personales, con tal valuación de su yo que esto acabó por cerrarle los ojos y la sensibilidad a todo lo que no fuera el sólo culto de sí mismo, y el cultivo de una sola fuerza, la de su egoísmo. Culto y fuerza, que llevados a su lógica consecuencia, le condujeron en la vida adonde su egoísmo, doblado de vanidad, hallase fácil satisfacción. En el Perú entre 1919 y 1930 uno de los medios de satisfacción fácil fué la sátira de todo y de todos, menos del dispensador del maná nacional, el "maestro de voluntades diamantinas, ese conquistador de todos los laureles que se llama Le- 
guía." $70 \mathrm{La}$ compensación o la ambivalencia en Guillén del insulto y la zalema, ambos provechosos a su egolatría, pueden estudiarse, por ejemplo, en una comparación de sus obras en prosa, La linterna de Diógenes y El libro de la democracia criolla. ${ }^{71}$ En la presentación misma de su poesía, el auto-bombismo de Guillén sólo tiene par en el practicado por Hidalgo. Como el segundo libro de éste, el segundo de Guillén, Deucalión (1920), llevaba también un "Atrio" de Valdelomar y además una "advertencia" de Luis E. Valcárcel, tun "epílogo" de Luis Velazco Aragón, un "colofón" de Guillermo Luna Cortland y un "apéndice" con opiniones sobre Guillén de no menos de dieciséis escritores. De cómo pudo haber obtenido esta serie de opiniones ( $\mathrm{y}$ aun de cómo pudo haberlas retocado) da pintoresca referencia la indignada nota de uno de ellos, Raúl Porras Barrenechea, quien protestó públicamente en la revista limeña Mundial de que Guillén le citase como diciendo "Alberto Guillén es el poeta de los versos perfectos", siendo así que: "Demás está declarar que yo no he dicho tal ingenuidad. Me remito al núm. 7 de esta revista en el que apareció el único artículo que me acuso de haber escrito sobre Guillén - no a iniciativa mía por cierto." 72

Resulta así que tratar de examinar los libros de poesía de Guillén de 1918 y de 1920 requiere entresacarlos de esa ganga de publicidad y de personalismos de que él mismo los rodeó. Al verlos luego como documentos del movimiento evolutivo de la poesía peruana de aquel momento se percibe en ellos, como en los de Hidalgo - y mejor aún que en los de Hidalgo- una línea de marcha de un poeta joven dentro de la crisis y la confusión del pensamiento y de la literatura de aquellos años: el camino del individualismo llevado al extremo. En el caso de Guillén, la crítica que en sus libros en verso $\mathrm{y}$ en sus libros en prosa hace de los valores del pasado y de los valores que le rodean, le conduce a una absoluta confianza en el valor superior de su propio yo, y le inspira un verdadero fetichismo de sí mismo en lo literario. Lo político lo entrega al fetichismo del hombre fuerte, Leguía, su protector, en quien reconoce un igual en otro campo de actividades. Así como él se ve a sí mismo grande, líder, conductor, en la obra poética, ve a Leguía, en la política, como un Hombre, un Jefe, un Caudillo, sin el cual el pueblo no sería más que un rebaño. ${ }^{73} \mathrm{En}$ el caso paralelo del Hidalgo de aquellos días, el egocentrismo y narcisismo filosóficos y literarios que le afecta- 
ban como a Guillén, le condujeron igualmente a considerarse un genio literario y a definir al Poeta como Dios y, en consecuencia, a sí mismo, Hidalgo, como Dios ; ${ }^{74}$ y en lo político también a un caudillismo, algo más variado e inconstante que el de Guillén, un caudillismo puro, el de cualquier caudillo. Ya se vió su admiración por Guillermo II de Alemania en 1916; luego ha afirmado que sólo cree en un Lenín, un Mussolini, un Haya de la Torre, y que es, por naturaleza, caudillista. ${ }^{75}$ Tema es este que corresponde tanto a la sociología como a la historia literaria peruanas de aquellos años y que debe señalarse aquí como un síntoma de una de las direcciones de los cambios literarios al reflejar las distintas direcciones conceptuales y filosóficas de su tiempo.

Hidalgo y Guillén, a pesar de todo, son en más de un punto, consecuencias inmediatas del modernismo. Por ejemplo, consecuencia del modernismo en estos escritores, entre 1915 y 1920, es el sentimiento de la forma poética que les domina hasta el punto de que, como hemos visto, en 1918, al declararse introductor de la enjundia filosófica del futurismo en la poesía castellana, Hidalgo repudia un aspecto del de Marinetti y proclama su adhesión a la rima. También es el individualismo estético de los modernistas lo que Hidalgo y Guillén llevan en esos años a sus últimas consecuencias de egolatría literaria y filosófica, cuando pierden el respeto por los modelos literarios y culturales que los modernistas respetaban. Llama la atención en este punto que, así como a los poetas modernistas el individualismo literario, el oído atento al ritmo interior de cada poeta, les llevó en los años antebélicos a una sofisticada introspección a menudo melancólica y pesimista, a Hidalgo y a Guillén ese individualismo, al extremarse en la circunstancia histórica de los años de la guerra, de primacía de la fuerza y de la violencia en el mundo, los condujo por el contrario a una convicción de la necesidad de la imposición de su yo, llena de una aparente alegría y de un gran optimismo en la virtud de su energético egoísmo; evidencia de la reacción distinta de dos tipos de individualistas de edades y generaciones distintas, bajo circunstancias distintas. Queda, pues, esa tónica poética de energismo, confianza en sí mismo y agresividad egoísta como el residuo más evidente de las tendencias de los dos escritores arequipeños en la poética peruana de los años de la primera guerra mundial. 
Por los del 1915 al 1917 en los que en Arequipa se constituyeron los grupos literarios de "El Aquelarre", el de Urquieta e Hidalgo, y el de la "La Bohemia andina", algo parecido ocurría en la ciudad norteña de Trujillo. Allí existía un grupo literario de buen tono social, cuyo parangón era el escritor Vicente Alejandro Hernández del que sólo he logrado ver un poema de ocasión:

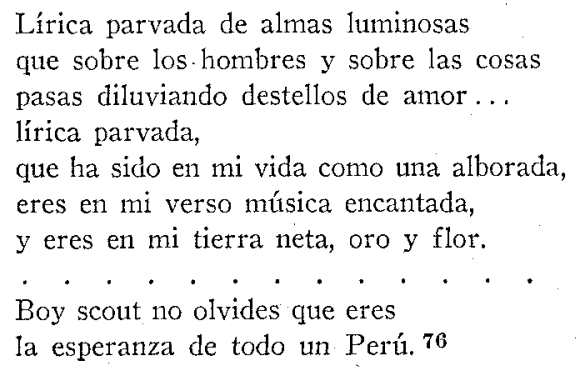

Frente a dicho grupo se situó otro, renovador y bohemio, que dirigían José Eulogio Garrido y Antenor Orrego Espinoza. De él formaron parte Alcides Spelucín (1897- ), Oscar Imaña, César Vallejo (1892-1928), Luis Armas, Santiago R. Vallejo, el pintor Macedonio de la Torre, Juan Espejo y, algo más tarde, Eloy Espinosa, Federico Esquerra, Leoncio Muñoz, Alfonso Sánchez Arteaga, Francisco Sandoval (1902- ) Juan Sotero, y Víctor Raúl Haya de la Torre (1895- ) Juan Parra del Riego que visitó a Trujillo en 1916 describió su asistencia a una reunión en la casa de Garrido durante la cual éste le dijo:

-Ahora le debo explicar a usted lo que es nutestra "La Bohemia." Todos estos señores que ve usted acá, poetas, novelistas, psicólogos, algunos genios ... nos reunimos en esta sala de mi casa los miércoles y sábados para hacer "dos horas de lectura." Naturalmente, vinculados por este eslabón intelectual nos paseamos juntos, de cuando en cuando almorzanios en grupo o hacemos, también en grupo, excursiones a las ruinas de Chanchán por las tardes o en noche de luna a las playas vecinas. Esta es nuestra terrible bohemia, señor Parra. ${ }^{77}$

En materia poética, durante esas reuniones, excursiones y paseos se leía y se recitaba a Rubén Darío, Nervo, Whitman, Verlaine, Paul Fort, Samain y Maeterlinck, y, naturalmente, también poesías de 
los miembros del grupo. No faltaron en esa bohemia los jaleos ni las burlas y provocaciones que suscitaron la hostilidad del grupo conservador; pero esos jóvenes tenían un serio propósito: elevar y enriquecer la cultura de Trujillo, tratar de renovar, de poner al día su tierra y su cultura que consideraban atrasadas, fosilizadas. Por aquellos días, antes de cristalizarse y dispersarse las respectivas vocaciones de los distintos miembros de "La Bohemia" de Trujillo, su actitud común era de lírica protesta contra el medio ambiente. De esa común actitud, de esa común desazón contra el mundo a su alrededor, surgieron con el tiempo un gran poeta, Vallejo; un excelente prosista, Garrido; un activista político y cultural, Orrego; y un líder político, Haya. Entre unos y otros, por sus distintos y divergentes caminos, lograrian conmover el ambiente no sólo de Trujillo sino de todo el Perú en los campos de la literatura, del pensamiento y de la acción.

Parra del Riego, en su referido artículo, señalaba que en aquel brillante grupo trujillano había dos poetas: Oscar Imaña y César Vallejo, ya que a Alcides Spelucín lo citaba como cuentista y no como poeta. En efecto, Imaña por aquel entonces publicaba versos en periódicos y revistas. En varios números de Balnearios, por ejemplo, de los años 1916, 1917 y 1919 pueden leerse poemas suyos que no desdicen de su calificativo de "poeta del dolor perfumado a lo Verlaine." Alcides Spelucín (1897- ), que en El libro de la nave dorada (1926) publicó su "labor poética de los años 1917-1921", andaba también por esos días muy rubendariano:

\author{
Marqués! \\ Oh, mi viejo y erguido Marqués! \\ Ciñe bien tu casaca rameada, \\ disimula el audaz peluquín, \\ que el amor, en amable emboscada, \\ hoy te espía a través del jardín. ${ }^{78}$
}

En el libro se encuentra toda la tropa siglo xvirI y todos los dioses y semi-dioses helénicos que pudiera apetecer el gusto modernista. Su nota diferencial respecto a éste y su paralelismo tendencial a la poesía de temática humilde y corriente se hallan en el parcial uso que hace de temas marinos de ambiente y tono cotidianos. Esto puede ser en parte derivación del parnasiano de la "Sinfonía en 
gris mayor", y del naturalismo del cuento "E1 fardo", por ejemplo, de Darío, y puede también ser consecuencia de una real familiaridad personal con la vida marítima. Así es que si todavía se encuentran en los versos de Spelucín de 1917-1921 barcas de oro que zarpan hacia Pafos de ensueño y Citeres más o menos funestas, también se encuentran viejos marineros rugosos, sus cachimbas humeantes, su tabaco Capstan, y los bares portuarios donde vigorosos capitanes de mar toman su gin. Es por esta nota de lo marítimo cotidiano y corriente por donde comienza Spelucín a salirse por aquellos años de su todavía predominante exquisito modernismo.

César Vallejo (1892-1938) que vivió, estudió y trabajó en Trujillo desde 1913 a 1918 era el poeta de "La Bohemia" trujillana a quien Juan Parra del Riego en su artículo citado de 1916 of recía "una violeta de aquellas que con hojas de hiedra coronaban a Alcibiades", $\mathrm{y}$ de quien un par de años más tarde decía otro visitante de Trujillo, Abraham Valdelomar: "Vallejo es un poeta. Hemos, por desgracia, abusado de este título. Vallejo es un poeta en la más noble acepción de la palabra." 79 Localmente, en Trujillo, se afirmaba de él: "ése que se dice poeta, ese César Vallejo, un hombre a quien le falta un tornillo... que si no es idiota, es cuando menos un loco", y, a sensu contrario: “Es un gran poeta! ¡Es un genio!” 80 La justificación de una u otra de esas opiniones debe hallarse en la poesía escrita por Vallejo durante esos años, cuya selección publicó en su libro Los heraldos negros (1918) a poco de trasladarse de Trujillo a Lima.

En la poesía contenida en Los heraldos negros se encuentran muy claramente las huellas de la influencia de Darío. En un poema titulado "Nochebuena", por ejemplo, figuran "ramajes" y "boscajes" que "perfuman de seda eburneos trajes", se oyen "charlas y risas en locas bandadas", y se declara que cuando aparezca la "epifanía de la forma esbelta" de la amada, "cantará la fiesta en oro mayor", todo lo cual deriva indudablemente de los "ramajes" y "el boscaje del amor palestra" en que las magnolias "acariciaban los sedosos trajes" de bellas mujeres mientras resonaban "las risas, locas fugas" de la divina Eulalia, "risa de oro", por más señas "en noche de fiesta"; y el "oro mayor", en Vallejo, procede también, claro está, del "gris mayor" y del "blanc majeur." ${ }^{81}$ Destellos de otras imágenes darianas pueden hallarse sin dificultad en otras poesías 
de Los heraldos negros. Más que de imágenes y de léxico se trata de un tono poético derivativo, resultado de la admiración de Vallejo por Darío. ${ }^{82}$ Clara es también en Heraldos la influencia de otro modernista, Leopoldo Lugones, especialmente de la tónica de Lunario sentimental (1909); por ejemplo, dice Vallejo: "Luna! Alocado corazón celeste / por qué bogas así, dentro la copa / llena de vino azul, hacia el Oeste", que de inmediato hace pensar en la lugoniana "Luna elegante en el nocturno balcón del Este; / Luna de azúcar en la taza de luz celeste; / Luna heráldica en campo de azur" y en la luna "Condenada a que bogue / con mortal desvarío." 83 Como en el caso del influjo de Darío podrían acumularse otros ejemplos de ciertas formas, hasta gráficas, y de ciertas imágenes lugonianas que resuenan en Los heraldos negros. Por fin, tan fuerte como la del mismo Darío y la de Lugones es sobre el Vallejo de los años quince al dieciocho la influencia de Julio Herrera y Reissig. Parra del Riego, el primer comentador en letra de molde de la poesía del Vallejo joven, dijo ya, al referirse a él en 1916, que "casi por todos sus versos se nota el paso de aquel poeta que tenía vestida de ave del paraíso la emoción, de Julio Herrera y Reissig." 84 A la luz de posteriores estudios la apreciación de la influencia del uruguayo sobre el primer Vallejo ha sido ampliada y precisada. ${ }^{85}$ Otras notas podrían añadirse demostrativas de la receptividad hacia la poesía de los grandes modernistas americanos por parte del César Vallejo de Los heraldos negros; pero tras de constatar los dejos modernistas de buena parte de ese libro conviene ver lo que haya en él de no modernista. Lo más diferente que a primera vista se nota en Heraldos con respecto al modernismo es cierto peruanismo, nacionalismo o localismo temático y léxicográfico en algunos poemas. Esta temática objetivamente pertana de ciertos poemas puede haber encontrado su arranque en la lectura de Herrera y Reissig y del mismo origen puede ser el empleo de materiales obtenidos de la vida cotidiana a su alrededor y el contraste o contraposición de lo exquisito con lo corriente y hasta con lo vulgar dentro de un mismo poema. Además, Vallejo debió también haber tomado ánimo para afirmarse en la visión poética de su provincia, de la familia, de la vida humilde y de lo cotidiano, en la poesía de Abraham Valdelomar $\mathrm{y}$ en los cuentos de este autor en los que se combinan las exquisiteces estilísticas con la cariñosa interpretación de la vida de los pue- 
blos de la costa peruana, de la familia patriarcal y modesta, de la naturaleza de la tierra nativa, de la vida diaria. No hay, por ejemplo, mucha distancia entre la inspiración de Valdelomar en: "Pasa un borracho hinchado el rostro / echa hacia mí su aliento fétido, / alza los brazos y gritando: / ¿Viva el Perú! se cae al suelo”, y la de Vallejo en: "Madrugada. Ia chicha al fin revienta / en sollozos, Iujurias, pugilatos; / entre olores de urea y de pimienta / traza un ebrio al andar mil garabatos." 86

Hay en Los heraldos negros, en efecto, cierto número de poemas de lo que puede llamarse peruanismo objetivo: "Un poyo con tres patas, es retablo / en que acaban de alzar labios en coro / la eucaristía de una chicha de oro", o "Como viejos curacas van los bueyes / camino de Trujillo meditando", etc., ${ }^{87}$ y cierta cantidad de léxico local: aguaitar, caja de Tayanga, capulí, coca, coraquenque, coricanchas, curacas, chacarero, chicha, chivatear, empanadas, ficus, huaino, huaco, etc., etc. Más notable, sin embargo, que este nativismo fácil y aparencial me resulta el localismo intimo de Vallejo, si por él ha de entenderse no "lo indio" o "lo mestizo" ancestral, sino el amor y la identificación del escritor con su tierra y con sus gentes, indios, mestizos o como fueren, la expresión literaria de una y otros tal como los ve y entiende el poeta en suámbito y en su tiempo, como algo más, como mucho más que como simple pintoresca materia de costumbrismo literario. Vallejo en poemas de Heraldos tales como "Oración del camino", "Huaco", "Aldeana", "Idilio muerto", o "Los arrieros", no resulta un indianizante como ciertos románticos, un exotizante de la propia América como Chocano, o un poeta idealmente cosmopolita como la mayoría de los modernistas, sino un poeta intrínsecamente de su tierra y de su tiempo y lo es sin necesidad de divorciarse por ello del género de su ser, de su esencia de hombre sin adjetivos accidentales. Véase, como ejemplo de ello, el final de su poema "Los arrieros":

\footnotetext{
Al fin tú llegarás donde debes llegar, arriero, qute, detrás de tu burro santurrón, te vas... te vas...

Feliz de ti, en este calor en que se encabritan todas las ansias y todos los motivos; cuando el espíritu que anima el cuerpo apenas,
} 
En este poema, que empieza hasta localizando la hacienda peruana para la que trabaja el arriero, esa localización no lo es específica del problema no sólo peruano sino humano, universal, que angustia al poeta, quien lo expresa en símiles peruanos, si se quiere, pero inteligibles a todos los que entienden su lenguaje y su conflicto.

Además de las notas de localismo objetivo y las expresiones de sentimientos generalmente humanos en términos de su localización geográfica, temporal e idiomática que separaban a Vallejo de la tónica cosmopolita y extraactual del modernismó, se confirma esta separación al constatar su tendencia a la poesía hogareña de la tonalidad que señalamos en Valdelomar por los mismos años, pero con mayor novedad expresiva en Vallejo que en Valdelomar. Si éste emplea, como notamos antes al transcribir su poema "El hermano ausente en la cena de Pascua", temas de la vida hogareña que los modernistas puros no hubieran tocado, to hace descriptivamente sin alcanzar la audacia metafórica de Vallejo en casos análogos. Por ejemplo, Valdelomar describe a la madre cuando "tiende a veces su mirada de miel"; la madre de Vallejo, ella, es "tan ala, tan salida, tan amor"; su padre, "es una víspera." 89 Es decir, Vallejo va un paso, un paso largo, más allá que Valdelomar en la sublimación literaria de su ambiente familiar: no lo describe, no lo interpreta, no lo sugiere; lo expresa.

Por fin, y como consecuencia de la profunda esencia humana de Vallejo que antes señalábamos, aparece en Los heraldos negros un tema intensísimo y reiterado, que por su misma intensidad y reiteración suena a nuevo en la poesía peruana, y es la expresión del sentimiento de la solidaridad de Vallejo con el dolor de los demás hombres. Los modernistas, salvo en momentos épicos o en tentativas mundonovistas, solían situarse en una posición completamente individualista, solitaria, respecto a los conflictos y los problemas de los demás seres humanos. Respecto al dolor, la desolación, el sentimiento de orfandad humana ante el destino, el modernista que los sufrió expresó el sufrimiento que experimentaba en sí y por sí. Otros poetas, contemporáneos de Vallejo, como Hidalgo y Guillén, aho- 
gan el propio dolor con arrogancia, sin debilidad, hasta sin quejas, y en su agresivo yoísmo lo compensan con el propio endiosamiento, con el desprecio por los demás hombres, con la exaltación de la fuerza, la violencia, porque superiores, violentos y fuertes se creían ellos mismos. Vallejo, en cambio, en un buen número đe los poemas de Los heraldos negros expresa humildemente la experiencia de la pobreza, el dolor, la desolación de esos años coincidentes con los desgarradores y crueles de la primera guerra mundial, y expresa en ellos no sólo su pobreza, su dolor, su desolación, sino, junto con ellas, la pobreza, el dolor, la desolación de todos los demás seres humanos que las sufren. En el poema liminar del libro, que da título a éste, Vallejo muestra la fatalidad de los golpes que caen sobre el hombre gratuitamente, sin que él haya hecho nada por merecerlos, golpes que proceden "como del odio de Dios", y que existen objetivamente: "Son pocos, pero son...", aunque el poeta no alcanza a explicarse su porqué : "¡ Yo no sé!" Frente a ellos “... el hombre... Pobre... pobre..." es objeto de la piedad fraterna del poeta que siente lástima y ternura por él. E1 hombre de "ojos locos" y con todo lo vivido empozado en su mirada, sufre esos "golpes sangrientos" sin saber por qué, fatalmente. ${ }^{90}$ Vallejo sospecha que el origen de la creación es indiferente hacia sus criaturas: "Dios mío, si tú hubieras sido hombre, / hoy supieras ser Dios; / pero tú, que estuviste siempre bien, / no sientes nada de tu creación." 91 Acaso el hombre, como el Segismundo calderoniano, paga el delito de haber nacido, delito del que tampoco es realmente culpable pues, como dice también Vallejo en otro poema: "Hasta cuándo este valle de lágrimas, a donde / yo nunca dije que me trajeran." " ${ }^{22}$ Es decir, Vallejo en 1918 ve la vida como algo irracional e irrazonable, sin explicación para los absurdos golpes de la fatalidad, los que avivan su compasión y su cariño hacia sus hermanos sufrientes. No es de extrañar tampoco que en aquellos años de guerra; muerte y destrucción en el mundo, el poeta extendiera su sentido de la irracionalidad del destino humano al destino cósmico y viera a la tierra como "un dado ródo y ya redondo / a fuerza de rodar a la aventura, / que no puede parar sino en un hueco, / en el hueco' de inmensa sepultura." "93 Pero a través de esta desesperación, el sentido de piedad por sí mismo y por los demás hombres, víctimas inocentes, se 
sublima en el poeta en un sentimiento de ser, con respecto a ellos culpable, culpable de algo, aunque no sepa de qué:

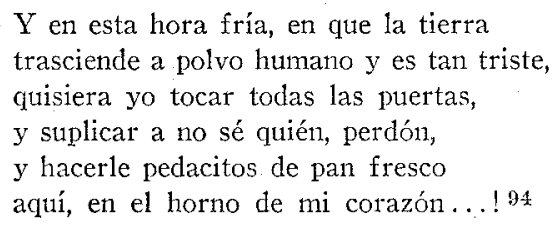

A tanto alcanza su sentimiento de solidaridad en el dolor con los demás hombres que cuando Vallejo en algún momento alcanza a estar relativamente bien, contento o feliz, se siente culpable porque durante esos instantes no ha participado de la carga total de pena injusta e irracional que pesa sobre los hombres: "Yo vine a darme lo que acaso esturo / asignado para otro; / y pienso que, si no hubiera nacido, / otro pobre tomara este café !" 950 o cuando una tarde "de alegre procesión de luces" siente que algo ajeno se 1e queda en las manos por no haber sufrido ese día tanto como los otros desventurados, cuando siente que puede haberles sustraído un gajito de dicha: "He salido a la puerta, / y me da ganas de gritar a todos: / Si echan de menos algo, aquí se queda! / . . Hoy no ha venido nadie; / y hoy he muerto qué poco en esta tarde." 96 En esta nota de emocional solidaridad del poeta con los otros hombres hállase, a mi entender, la expresión que le sitúa en una circunstancia literaria ya completamente fuera del arte por el arte modernista. Esta nota pudiera llamarse el sentimiento de responsabilidad humana del poeta hacia los otros hombres y por los otros hombres tanto en el arte como fuera de él.

En Los heraldos negros - la poesía de César Vallejo escrita durante los años de la primera guerra mundial- el artista se muestra en parte atado todavía a las maneras literarias modernistas predominantes en los años en que él comenzó a escribir; pero al mismo tiempo se perciben en sus versos diversas vías que le llevan a una poesía distinta y alejada de la modernista: la temática y el lenguaje localistas es sólo una de esas vías; el intimismo es otra; pero la que hoy sabemos que iba a ser la más fecunda en la obra literaria posterior de Vallejo y en su significado en la poesía de su tiempo es ese reconocimiento, germinal y puramente emocional en Los he- 
raldos negros, de la solidaridad humana (en el dolor por ahora, más tarde en la rebelión y luego en el activismo contra las causas de ese dolor común) como materia poética lírica. En su aspecto todavía modernista de Los heraldos negros, Vallejo desciende de Darío, Lugones y Herrera y Reissig; en su localismo objetivo y aparencial pudiera ser paralelo peruano del "mexicanismo" o "provincialismo" de López Velarde, por ejemplo; en su intimismo, anda con mayor audacia expresiva que Valdelomar, su iniciador en el Perú, por el camino poético indicado por éste; pero en su personal manera y pensamiento señala una dirección de la poesía peruana divergente $\mathrm{y}$ contradictoria de la de sus coetáneos Hidalgo y Guillén, por ejemplo, y es el pionero en la expresión del sentimiento de la solidaridad con el dolor de todos los hombres, lo que refleja, me parece, además de la propia angustia anímica de Vallejo su percepción de las angustias y sufrimientos de tantos seres humanos en los días de la revolución mexicana, de la primera guerra mundial y de la revolución rusa. Vallejo mismo podrá no haberlo comprendido por esos años, pero con la expresión de ese sentimiento en su poesía inicial había dado, emocionalmente, el primer paso por el camino que había de llevarle primero a una actitud de bohemia rebelión individual contra el medio ambiente y más tarde al servicio de ideas que le ofrecían la esperanza de poner un término y una solución humana a las causas del dolor común. Uno y otra los habría de expresar en poesía que Heraldos apenas inicia. En las nuevas tendencias de la poesía peruana ésta es la que, en mi opinión, debe identificarse como la más específicamente vallejiana.

Los poetas cuya labor de 1915 a 1920, más o menos, se ha descrito, pueden considerarse como representativos de las principales tendencias peruanas de esos años, como poetas transicionales del modernismo hacia otros tipos de poesía. Más poetas podrían mencionarse sin alterar por ello los lineamientos generales del diseño. Debe decirse, sin embargo, que entre esos poetas, aun entre los más jóvenes, se encontraban algunos, como Federico Bolaños (1896- ), que seguían fielmente las huellas de Darío ("Solemnes custodian cien glaucos puñales / el lirio que hospeda dormido diamante") y de Chocano (“¿Dónde están, dime, tus legendarios laureles, / tu pomposa progenie y tus soberbias palmas?"). ${ }^{97}$ Otros, como José Chioino (1898- ), eran simbolistas que aun recono- 
ciendo que "Reconstruir un estado de alma con palabras, es como hacer con papeles y alambre una rosa", ${ }^{98}$ no dejaban por ello de intentarlo. U otros, como Daniel Ruzo (1900- ), premiado en los Juegos Florales de 1918 y proclamado por los universitarios limeños "Poeta de la Juventud", continuaban entre ésta la tradición musical verlainiana, bien que en un tono de tout répos y con ganas de "vivir dulcemente los minutos / sin pensar en la vida." "99 Varios fueron también los que seguían las rutas paisajistas trazadas por Gibson y Valdelomar al "canto violinesco de un gallo", o el localismo más aparencial y objetivo de Vallejo: "Los ccuris, como peregrinos / llenos de cansancio caminan." 100 Otros se inclinaban más al yoísmo ególatra de Hidalgo y de Guillén, como aquél que dijo: "Yo seré tal vez un anormal; pero no soy un adocenado", ${ }^{101}$ a pesar de que, literariamente, resulta sin duda lo segundo. Otro, Ernesto More (1897- ), en el prólogo de su libro de versos Hesperos (1918) 102 declaraba iniciar el "andinismo" poético, de lo que habré de ocuparme en otra ocasión al tratar del nativismo literario. Para acabar mencionaré a Luis Berninsone que en 1917 publicó un libro, Walpírgicas, de cuyo prólogo no puedo resistir la tentación de reproducir las siguientes líneas:

no se deriva este título [Walpúrgicas] del Walpurgis fanstiano, descripción bastante deficiente de la noche del Sabat, ridículamente incompatible con la teosófica personificación genial de Mefisto; ni tampoco es mixtificada asimilación de la cábala baudelairiana, insincera, como las prosas versificadas del maligno floricultor de sus poemas. El título de mi libro, es tan sólo, derivado de la nigromancia idiosincrásica, en mi siquis sintetizante de la urdimbre de tenebrosismos y exentricidades de una ingénita originalidad directamente relacionada con la onomatópica interpretación a auspicios del místico misterio invocador de Santa Valpurgis... ${ }^{103}$

De cuyo texto sólo puedo decir que es un excelente ejemplo de superevaluación yoísta, de desprecio del pasado y de la obra ajena, y de la más completa confusión, no atípica de los confusos días en que fué escrito.

En resumen, los poetas peruanos durante los años de la primera guerra mundial iban saliendo del modernismo y se encaminaban hacia nuevos tipos de poesía. Las causas de ese movimiento de salida pueden ser, en lo formal, la fatiga por la repetición estilística a 
través de los años y, en lo filosófico, la crisis intelectual producida por el comienzo de quiebra del mundo ctyo reflejo literario había sido el modernismo. Las principales tendencias literarias pertuanas de esa salida parecen ser: 1. la readmisión de 1o intuitivo en la literatura, en contraste con la consciencia literaria de los modernistas; 2. la adopción de una temática de lo cotidiano, corriente, vulgar, nimio, en contraposición a la temática exquisita del modernismo; 3. la afirmación de una visión literaria de lo local, lo provincial, lo nacional, en oposición al cosmopolitanismo y exotismo literarios de los modernistas; 4 . la entrada en la literatura poética de la nueva vida deportiva y maquinística, contemporánea, en contraste con el vivir mentalmente eis la antigüedad o en el siglo xviı francés de tantos modernistas; 5. la influencia de una escuela europea "de vanguardia", el futurismo, y de su desprecio por el pasado en quiebra, en contraste con las influencias del parnasianismo y del simbolismo y sus acarreos culturales admirados por los modernistas; 6 . la expresión admirativa y optimista ante la futerza y la violencia, y el tritunfo de la voluntad fuerte (aun la irracional y arbitraria) trasladada al campo cultural, en contraste con el racionalismo; el eclecticismo y la ecumenicidad del modernismo; 7. la expresión poética de la solidaridad de los hombres ante el dolor de los efectos de ese irracionalismo sobre la humanidad, en contraste con la actitud generalmente abstencionista y au dessus de la melée de la mayoría de los modernistas ante los problemas colectivos.

Estas distintas tendencias son, como se ve, a veces complementarias las unas de las otras, a veces divergentes, a veces contradictorias. Ello es resultado del estado de crisis en la realidad circundante que redundaba en una crisis filosófica, cultural y literaria durante los años bélicos y revolucionarios del 1914 al 1920, según a su comienzo había percibido Gálvez. ${ }^{104}$ De todas estas tendencias, en una $u$ otra forma, se percibirán los frutos en la sucesiva poeșía pertuana: de la ruptura con el pasado, en la poesía vanguardista; del nacionalismo literario, en la poesía nativista; de la afirmación de la solidaridad con los que sufren, en la poesía social; de la readmisión de lo intuitivo, en la poesía de aire superrealista.

Luis Monguró, Mills College, California. 


\section{$\mathrm{NOTAS}$}

1 José Gálvez Barrenechea, Posibilidad de una genuina literatura nacional (El peruanismo literario). [Tesis para optar el grado de Doctor en la Facultad de Filosofía y Letras de la Universidad Mayor de San Marcos de Lima.] (Lima: Casa Editora M. Moral, 1915), pp. 66 y 68.

2 "Nuestros reportajes. Con Abraham Valdelomar en el Parque del Barranco", Balnearios, Lima, núm. 293, 14 enero, 1917.

3 De "Yo soy aquél que ayer no más decía", de Cantos de vida y esperanza (1905), en Rubén Dario, Poesias completas, ed. Alfonso Méndez Plancarte. (Madrid: Aguilar, 1952), p. 690.

4 "Nuestros reportajes", cit, núm. 2, supra.

5 Ibid.

6 "El Conde de Lemos y Máximo Fortis. Cartas cruzadas con motivo de la aparición de El caballero Carmelo", Studium, Lima, núm. 7, marzo, 1921, pp. 222-223.

7 Las voces múltiples (Lima: Librería francesa científica de E. Rosay, 1916), p. 200. ("Tristitia".)

8 "El hermano ausente en la cena de Pascua", en Balnearios, Lima, núm. 229, 24 octubre, 1915, y en Voces muiltiples, pp. 221-222.

9 Voces múltiples, p. 202. ("Nocturno".)

10 "Abraham Valdelomar triunfa en Trujillo", Balnearios, Lima, núm. 364, 26 mayo, 1918.

11 "E1 Conde de Lemos y Máximo Fortis", (cit. núm. 6, supra), 223.

12 Alberto Tauro, "Colónida en el modernismo peruano", y "Bibliografía de Colónida", Revista Iberoamericana, México, I, (1939), 1, 77-82, y 3, 461467, respectivamente; y en Letras, Lima, núm. 15, primer cuatrimestre 1940, 81-91. Del "movimiento colónida" escribió José Carlos Mariátegui, por ejemplo, en "Nacionalismo y vanguardismo en la literatura y el arte", Mundial, Lima, núm. 286, 4 diciembre, 1925, y también en su libro Siete ensayos de, interpretación de la realidad peruana, (Lima: Editorial Amauta, 1928), 264 pp., etc. Esta o parecidas expresiones han empleado muchos críticos e historiadores de la literatura pertuana.

13 Ventura García Calderón, La literatura peruana (1535-1934). (New York-París: Extrait de la Revue Hispanique, Tome xxxI, 1914), $91 \mathrm{pp}$. 
14. Federico More, "La hora undécima del señor don Ventura García Calderón", Colónida, Lima, núm. 2, 1 febrero, 1916, 35.

15 Según nota en la contraportada de Cultura, Lima, núm. 1, junio, 1915.

16 Alberto Tauro, "Contemporáneos y Cultura, dos revistas de la generación modernista", Letras, Lima, núm. 9, primer cuatrimestre 1938, 134-155. Re. Gálvez v. 11. 1, supra.

17 Las voces múltiples, (Lima: Librería francesa científica de E. Rosay, 1916), 249-IV pp. Contiene poemas de Pablo Abril y de Vivero, Hernán C. Bellido, Antonio Garland, Alfredo González Prada, Federico More, Alberto Ulloa Sotomayor, Abraham Valdelomar y Félix del Valle.

18 Voces múltiples, p. 30, ("Los crepúsculos del amor, V").

19 Voces múltiples, pp. 130-131, ("Después de su desdén y de mi sueño").

20 Voces múltiples, p. 78, ("París sonríe"). Fechado en "Barcelona, 1915", este poema había aparecido también en Variedades, Lima, núm. 410, 8 enero, 1916.

21 Balnearios, Lima, núm. 109, 10 noviembre, 1912.

22 Balnearios, Lima, núm. 145, 20 julio, 1913, y núm. 146, 27 julio, 1913.

23 "Los cisnes negros", Balnearios, Lima, núm. 176-177, 19 marzo, 1914; "De un amor que se fué...", Balnearios, núm. 224, 19 septiembre, 1915, y Lulú, Lima, núm. 43, 18 mayo, 1916, p. 17; "La tarde es una ojera...", Balnearios, núm. 234, 28 noviembre, 1915.

24 Balnearios, Lima, núm. 158, 19 octubre, 1913.

25 Ariel, Arequipa, núm. 2, 4 enero, 1916; Balnearios, Lima, núm. 247, 27 febrero, 1916; Lulú, Lima, núm. 45, 1º junio, 1916.

26 "Tierra de Chiclayo...", Balnearios, Lima, núm. 208, 30 mayo, 1915; "Ignal desde los tiempos...", Balnearios, núm. 242, 23 enero, 1916; "E1 poeta canta...", Balnearios, núm. 280, 15 octubre, 1916.

27 Estuardo Núñez, "Semblanzas - Juan Parra del Riego, poeta de América", IPNA [Instituto Peruano-Norte-Americano], Lima, iI, núm. 4, 1945, pp. $42-46$.

28 Juan Parra del Riego, Poesía. (Montevideo: Ministerio de Instrucción Pública, Biblioteca de Cultura Uruguaya, 1943), pp. 180-182. Con indicación de haber sido publicado el poema en Calibán, Montevideo, mayo, 1922.

29 Henri de Montherlant, Première Olympique: Le Paradis à l'ombre des epées, (Paris: B. Grasset, 1924), 190 pp.; Deuxième Olympique: Les onze devant la porte dorée, (Paris: B. Grasset, 1924), 244 pp.; Les Bestiaires, (Paris: B. Grasset, 1926), 298 pp. 
30 Parra, Poesía, p. 46.

31 Ibid, p. 182.

32 Juan Parra del Riego, Prosa, (Montevideo: Ministerio de Instrucción Pública, Biblioteca de Cultura Uruguaya, 1943), pp. 211-212. Carta de Parra a Bernardo Canal Feijoo, algo anterior al 24 de junio de 1918.

33 Francisco Mostajo, El modernismo y el americanismo [con Los modernistas peruanos]. (Arequipa: Imprenta de la Revista del Sur, 1896), p. 52.

34. Augusto Renato Morales de Rivera, Cirrus (Poesías), prólogo de Francisco Mostajo (Arequipa, 1909), 43 pp. Hace unos años apareció otro libro con su obra poética bajo el título de Sus versos, Recopilación póstuma, (Lima: Compañía de Impresiones y Publicidad, 1940), 133 pp.

35 "Evangelio democrático", Colónida, Lima, núm. 3, 1 marzo, 1916, pp. 28-35, y núm. 4, $1^{\circ}$ mayo, 1916, pp. 15-17; Jornada heroica, Trompetería en tono mayor al Dos de Mayo, Poema, (Arequipa: Editorial Quiroz, 1916), $54 \mathrm{pp}$.

36 V., por ejemplo, Cultura, Lima, núm. 1, junio, 1915.

37 César A. Rodríguez, La torre de las paradojas, (Buenos Aires: Editorial Nuestra América, 1926), 176 pp.

38 Balnearios, Lima, núm. 227, 10 octubre, 1915.

39 Colónida, Lima, núm. 2, $1^{\circ}$ febrero, 1916, pp. 20-21.

40 V. Augusto Aguirre Morales, "Literatos jóvenes de Arequipa", Colónida, Lima, núm. 2, 1 febrero, 1916, pp. 16-19; Emilio Romero, "La vida literaria en el Sur del Perú", Mundial, Lima, núm. extraordinario, 9 diciembre, 1924; Emilio Romero, "Recuerdos literarios", La Sierra, Lima, núm. 24, diciembre, 1928, pp. 10-12. El doctor Vladimiro Bermejo, profesor y bibliotecario de la Universidad Nacional de San Agustín, a mi paso por Arequipa (1952), tuvo la gentileza de comunicarme unas notas suyas, inéditas, que me han permitido confirmar o rectificar algunos datos de los artículos referidos.

41 Alberto Hidalgo, Arenga lirica al Emperador de Alemania y otros poemas, (Arequipa: Tipografía Quiroz Hermanos, 1916), prólogo de Miguel Angel Urquieta, pp. xxviII y xxI.

42 Hidalgo, Arenga, p. 39, ("Reino interior").

43 Hidalgo, Arenga, pp. 29-35, ("Canto a la guerra"). Más tarde ha escrito: "Soy antiguerrero. Pero lo peor de la guerra es que aniquila la razón. El corazón vence al cerebro, indefectiblemente. En la conflagración de 1914 fuí germanófilo sólo porque, siendo adolescente, me fascinó la belleza de la fuerza. Mas si hubiese una nueva guerra y la justicia no estuviera del lado de Alemania, sería nuevamente germanófilo." (Diario de mi sentimiento, 
1922-1936. [Buenos Aires: Edición Privada, Talleres Gráficos Excélsior, 1937], p. 345$)$.

44 Hidalgo, Arenga, pp. 39-40, (De "Reino interior").

45 Tidalgo, Arenga, p. xxvr, (del prólogo de Urquieta). A título de curiosidad y como ejemplo de esa temprana auto-apreciación de Hidalgo transcribo la siguiente dedicatoria autógrafa suya que figura en un ejemplar de la Arenga (1916), existente en la Biblioteca Nacional de Lima (Signatura: 869.58 - H63A81): "A usted Miguel Anjel Urquieta, mi buen amigo, mi querido hermano, le ofrendo este libro con el afecto mas cordial i la mas franca admiración. / Venidos los dos, mas o menos al mismo tiempo, a luchar en los campos del Talento contra los mediocres i los malos, estamos unidos por el mismo esfuerzo, por el mismo ideal. Nadie se atreverá a dudar de nuestra llegada. El triunfo de nuestro jenio es el Porvenir quien tendrá que confirmarlo. / I a modo de profecía de ese mañana que ansioso espero, hai le envío, con un robusto apretón de manos, mi aplauso fervoroso $\mathrm{i}$ mi augurio entusiasta; i como prueba de cariño i gratitud, le entrego, en altivo arranque de sinceridad, lo mas valioso que hai en mí: el Corazón. / Alberto Hidalgo. / En 5 de set. de 1916."

46 Alberto Hidalgo, Panoplia lírica, (Lima: Imprenta Víctor Fajardo, 1917), 188 pp.

47 Clemente Paima, "Notas de arte y letras", Variedades, Lima, núm. 454, 11 noviembre, 1916.

48 Hidalgo, Panoplia, pp. 95-99, ("La nueva poesía. Manifiesto").

49 Hidalgo, Panoplia, pp. 111-115, ("Oda al automóvil").

50 "Un automobile ruggente, che sembra correre sulla mitraglia, è piu bello della Vittoria di Samotracia", punto 4 de los once sentados por F. T. Marinetti en su manifiesto de 1909. Citado por Giuseppe d'Arrigo, Il poeta futurista Marinetti, Sintesi della vita e dell'azione, (Roma: Edizioni della Lupa, 1937), p. 23.

51 Alberto Hidalgo, Las voces de colores, (Arequipa, 1918), p. xv.

52 Alberto Hidalgo, Joyería, (Poemas escogidos). (Buenos Aires: Virtus, 1919), 133 pp. [Contiene una selección de Panoplia lirica y de Las voces de colores y una nueva serie de poemas titulada: "La sombra de Hércules"].

53 Para su opinión sobre la democracia, en esos años, v. su Jardin zoológico, (Arequipa: Tipografía Quiroz Perea, 1919), núm. 26, pp. 252-253.

54 Hidalgo, Jardin zoológico, núm. 34, p. 255.

55 V. Hombres y bestias, Bocetos criticos. (Arequipa, 1918), 211 pp.; Jardín zoológico, (Arequipa: Tipografía Quiroz Perea, 1919), 308 pp.; Muer- 
tos, heridos y contusos, (Buenos Aires: Imprenta Mercatali, 1920), 160 p.; España no existe, (Buenos Aires, 1921), 155 pp.; passim.

56 Hidalgo, Toces, p. xvir.

57 Hidalgo, Voces, pp. 89-90.

58 Hidalgo, Joyería, p. 119.

59 "Emilio Romero, "La vida literaria", cit. núm. 40, supra.

60 Por ejemplo, Hidalgo comienza a imprimir poemas en Balnearios, de Lima, a partir del núm. 225, de 26 septiembre, 1915 ("Autorretrato", "Yanta aldeana"), mientras que la primera aparición de Guillén en la misma revista ocurre sólo en el núm. 347, de 27 enero, 1918 ("La emoción musical").

61 Alberto Guillén, Prometeo, (Arequipa: Tipografía Quiroz Perea, 1918, p. vir, "Pórtico" por Alberto Hidalgo.

62 Guillén, Prometeo, pp. xix-xx.

63 V. Alberto Hidalgo, Diario de mi sentimiento, p. 110; y S. R. [Salvador Reyes], "15 minutos con Alberto Guillén", Letras, Santiago de Chile, febrero-marzo, 1929.

64 Guillén, Prometeo, p. 34.

65 Guillén, Prometeo, p. 88. Eco del "I celebrate myself, and sing myself", whitmaniano. (Walt Whitman, Leaves of Grass [1855], ed. Emery Halloway. [New York: Doubleday, 1924], p. 24).

66 Guillén, Prometeo, p. 93.

67 Darío, Poesías completas, ed. Méndez Plancarte, pp. 820 y 595.

68 Alberto Guillén, Deucalión. (Lima: F. E. Rosay, 1920), pp. 5-6.

69 Guillén, Deucalión, p. 142.

70 Alberto Guillén, Laureles. (Imprenta Lucero, 1925), 87 pp. sin numerar.

$71^{\prime}$ Alberto Guillén, La linterna de Diógenes. (Madrid: Editorial América," 1921), 269 pp.; 2a ed., aumentada. (Madrid: La Aurora Literaria, 1923), 404 pp.; El libro de la democracia criolla. (Lima: Imprenta Lux, 1924), 119 pp.

72 Raúl Porras Barrenechea, "Alberto Guillén y su libro Deucalión", Mundial, Lima, núm. 39, 21 enero, 1921.

73 Guillén, Libro de la demòcracia criolla, pp. 13, 32, et passim.

74 Hidalgo, Arenga, p. 40; Jardin zoológico, p. 255. 
75 Hidalgo, Diario de mi sentimiento, p. 177.

76 Vicente Alejandro Hernández, "Versos dichos por su autor en la velada que se organizara en họnor de la 'Brigada de Boy Scouts del Barranco' que excursionó a la ciudad de Trujillo y que se realizó en el Cine-Idea, en la noche del 9 de agosto de 1916", Balnearios, Lima, núm. 289, 17 diciembre, 1916.

77 Juan Parra del Riego, "La Bohemia' de Trujillo", Balnearios, Lima, núm. 281, 22 octubre, 1916. Sobre los grupos literarios de Trujillo, ver también: Antenor Orrego, "Prólogo" a César Vallejo, Trilce. (Lima: Talleres Tipográficos de la Penitenciaría, 1922), p. xI; Antenor Orrego, "Panorama intelectual de Trujillo", La Sierra, Lima, núms. 13-14, enero-febrero, 1928, pp. 26-28; Abraham Arias Larreta, "Panorama de la literatura peruana", Revista Iberoamericana, México, xiv, 27, 15 junio, 1948, 103 ; André Coyné, "Apuntes biográficos de César Vallejo", Mar del Sur, Lima, núm. 8, noviembre-diciembre, 1949 , p. 55.

78 Alcides Spelucín, El libro de la nave dorada (Poemas), (Trujillo: Ed. E1 Norte, 1926), p. 145.

79 Parra, "La Bohemia' de Trujillo", cit. núm. 77. "Hablando con el señor Valdelomar. Sus impresiones de Trujillo. La ciudad colonial y la ciudad moderna. Su jira por el Norte. El desarrollo artístico local. Reproducción de un reportaje que le fué hecho en La Reforma, de Trujillo", Balnearios, Lima, núm. 364, 26 mayo, 1918.

80 Ciro Alegría, "El César Vallejo que yo conoci", Cuadernos americanos, México, III, 6, noviembre-diciembre, 1944, p. 177.

81 César Vallejo, Los heraldos negros, (Lima, 1918), pp. 15-16, ("Nochebuena"); Darío, Poesias completas, ed. Méndez Plancarte, pp. 597-599, ("Era un aire suave" [1893]), pp. 645-646, ("Sinfonía en gris mayor [1891]; y Théophile Gautier, Emaux et Camées (1852), ed. Jacques Madeline (Paris: Hachette, 1927), pp. 25-27, ("Symphonie en blanc majeur").

82 Como muestras de esa admiración v. por ejemplo, el poema "Retablo", en Heraldos, pp. 119-120, o el artículo "Estado de la literatura española", en Favorables Paris, poema, París, núm. 1, julio, 1926, pp. 6-7, en el que aparece la frase: "la historia de la literatüra española saltará sobre los últimos treinta años, como sobre un abismo. Rubén Darío elevará su gran voz inmortal desde la orilla opuesta y de esta otra, la juventud sabrá lo que ha de responder:"

83 Vallejo, Heraldos, pp. 7-8, ("Deshojación sagrada"); Leopoldo Lugones, Obras poéticas completas, (Madrid: Aguilar, 1948), p. 214, ("Himno a la luna") y p. 284 ("E1 sol de medianoche").

84 Parra, "La Bohemia' de Trujillo", cit. 
85 V. Jorge Bassadre, "Un poeta peruano", La Sierra, Lima, núms. 1314, 1928, pp. 30 y 32; José Carlos Mariátegui, Siete ensayos de interpretación de la realidad peruana (1928), 2a ed. (Lima: Biblioteca Amauta, 1942), p. 241; Alcides Spelucín, "trayectoria literaria de César Vallejo", Presente, Lima, núm. 3, $2^{\circ}$ semestre 1931 , p. 9, etc., y especialmente, el detallado estudio de esa influencia realizado por André Coyné en "L'oeuvre poétique de César Vallejo" (1950), tesis inédita de la Universidad de París.

86 "Nocturno" de Abraham Valdelomar en Las voces míltiples, p. 202; y "Terceto autóctono, Im", de Vallejo, en Heraldos, p. 73.

87 Vallejo, Heraldos, pp. 64 y 65, ("Nostalgias imperiales, I" y "III")

88 Vallejo, Heraldos, p. 138.

89 Vallejo, Heraldos, pp. 144 y 148, ("Los pasos lejanos" y "Enereida").

90 Vallejo, Heraldos, pp. 3-4.

91 Vallejo, Heraldos, p. 123, ("Los dados eternos"). Compárese el concepto que Vallejo tenía de la irracionalidad de la vida y de la indiferencia del Creador con el apóstrofe de Hardy: "O Loveless, Hateless! / past the sense / of kindly eyed benevolence, / to what tune danceth this Immense?" (Thomas Hardy, The Dynasts [1908], 2d. ed., vol. 3. [London: Macmillan \& Co., 1910], p. 353).

92 Vallejo, Heraldos, p. 112, ("La cena miserable").

93 Vallejo, Heraldos, p. 124, ("Los dados eternos").

94 Vallejo, Heraldos, p. 100, ("El pan nuestro").

95 Ibid.

96 Vallejo, Heraldos, pp. 91-92, ("Agape").

97 Federico Bolaños, Atalaya. (Lima: Imprenta Berrios, 1922), p. 23, ("E1 lirio") y p. 49 ("Apóstrofe a la Raza"). p. 7.

98 José Chioino, Flores artificiales. (Lima: Editora E. R. Villarán, 1921),

99 Daniel Ruzo, Asi ha cantado la Naturaleza. (Lima: La Opínión Nacional, 1920), p. 161 .

100 J. Mario Chávez, Alma. (Arequipa: Edición del autor, 1922), p. 38, ("Aurora") y p. 44 ("Preludio".)

101 Luis Zanatta, Sueños de pubertad, poesías. (Lima: Imprenta E. Z. Casanova, 1918), p. vi. 
102 Ernesto More, Hesperos y "El dia de los buhos" con música de Gonzalo More. (Lima, 1918), xx-103 pp.

103 Luis Berninsone, Walpurgicas, poemas. (Lima: Tipografía y Encuadernación de la Penitenciaría, 1917), p. I.

104 V. Re. de la núm. 1, supra. 
